\title{
A case of Di George anomaly
}

\author{
C P Goonesekera ${ }^{1}$, D Perera ${ }^{2}$, S Waidyanatha ${ }^{3}$
}

Sri Lanka Journal of Child Health, 2005; 34: 18-9

(Key words: Di George anomaly)

\section{Introduction}

Di George anomaly (DGA) is a congenital immunodeficiency characterized by abnormal facies, congenital heart disease and increased susceptibility to infections. Pathological hallmarks include conotruncal abnormalities and absence or hypoplasia of thymus and parathyroid glands. Although commonly known as $\mathrm{Di}$ George syndrome, the term Di George anomaly is more appropriate $^{1}$. The constellation of defects is not a syndrome resulting from a single cause, but rather the failure of an embryological field to develop normally ${ }^{2,3}$. In the past, the incidence of DGA was estimated to be $1 / 20,000$, but with the advent of fluorescence in situ hybridization (FISH) technique to detect microdeletions of chromosome- 22 and the inclusion of related syndromes, more recent estimates place the incidence of DGA and velocardiofacial syndrome in the range of $1 / 3000$ persons $^{2}$.

\section{Case report}

A $6 \frac{1}{2}$ year old boy from Paiyagala was admitted to our ward for treatment of lower respiratory tract infection. On admission, the child was febrile and dyspnoeic. He was of average build with a body weight of $18 \mathrm{~kg}$ and an abnormal facies. An apparent hypertelorism, prominent low set ears with abnormal simple pinnae and a bulbous nose with a short philtrum were the most obvious facial features noted (Figure 1). No evidence of fungal infections was seen. There were diffuse crepitations and rhonchi over the lungs. There was a grade 2 , early systolic murmur heard over the pulmonary area. Rest of the examination was normal.

Chest x-ray, taken on admission, demonstrated a narrow superior mediastinum. 2D-echocardiography showed a mild pulmonary stenosis.

${ }^{1}$ Registrar, General Hospital, Kalutara, ${ }^{2}$ Registrar, Colombo South Teaching Hospital, ${ }^{3}$ Consultant Paediatrician, General Hospital, Negombo.

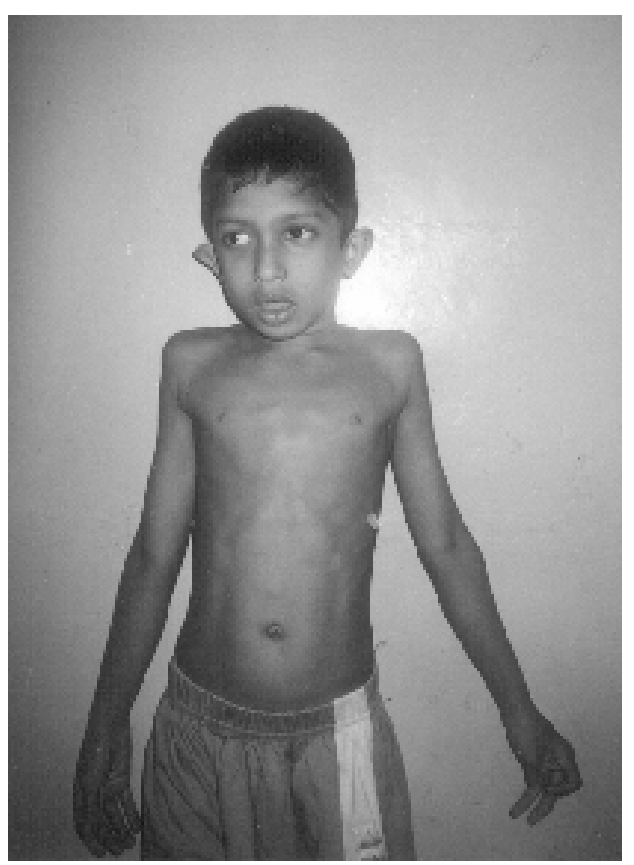

Figure 1 Facial features in Di George anomaly

This is a patient where absent or hypoplastic thymus was suspected during early infancy and hypocalcaemia had been demonstrated repeatedly. At age of four months a futile attempt had been made to demonstrate the thymus ultrasonically. Chest x-rays taken at that time had revealed a narrow superior mediastinum. During the 1st year of life he had been admitted thrice for treatment of recurrent sinopulmonary infections. During infancy he had been on calcium supplements. No evidence of hypocalcaemic tetany or convulsions was noted. Later on, child was lost to regular follow-up, but had got treatment for recurrent sinopulmonary infections at the outpatients department until December 2003, when he got admitted to our ward.

The following investigations were done:

Parathyroid hormone level $<1 \mathrm{pg} / \mathrm{ml}$ (normal range $7-53 \mathrm{pg} / \mathrm{ml})$. 
Flow-cytometry for T and B-lymphocytes in peripheral blood

$$
\begin{array}{lll}
\text { CD } 4 & 30.9 \% & \text { (normal) } \\
\text { CD } 8 & 25.5 \% & \text { (normal) } \\
\text { T-cells } & 58.4 \% & \text { (normal) } \\
\text { B-cells } & 17.6 \% & \text { (normal) } \\
\text { NK-cells } & 8.7 \% & \text { (normal) }
\end{array}
$$

Serum immunoglobulins:

$$
\begin{array}{lll}
\text { IgG } & 867.6 \mathrm{mg} / \mathrm{dl} & \text { (normal) } \\
\text { IgM } & 942.2 \mathrm{mg} / \mathrm{dl} & \text { (normal) } \\
\text { IgA } & 37.0 \mathrm{mg} / \mathrm{dl} & \text { (low) }
\end{array}
$$

Serum calcium $1.97 \mathrm{mmol} / \mathrm{l}$ (low)

Serum phosphate $1.82 \mathrm{mmol} / \mathrm{l}$ (normal)

\section{Discussion}

DGA belongs to a group of disorders described as developmental field defects ${ }^{2}$. It is sporadic though familial cases are reported. It is the most frequent contiguous gene deletion syndrome in humans ${ }^{2}$. Using FISH probes $>90 \%$ of patients with DGA have a micro-deletion of ch.22q11.21 through 22q11.232.

DGA anomaly is heterogeneous with partial forms more common than complete phenotype ${ }^{1,4}$. Whilst classically recognized by the triad of congenital defect, immunodeficiency secondary to thymic hypoplasia and hypocalcaemia secondary to parathyroid gland hypoplasia, an expanded phenotype is increasingly recognized with dysmorphic facies and associated phenomena such as hearing difficulties, renal ano-malies, neuropsychiatric disorders and autoimmune phenomena $^{4,5}$.

Severe T-lymphocyte immunodeficiency presenting with a SCID phenotype is rare accounting for $<1.5 \%$ of cases ${ }^{4}$. Humoral immunodeficiency is commoner and improves with time, patients presenting with recurrent sinopulmonary infections ${ }^{4}$. The commonest cardiac lesion is of the conotruncal type although the incidence seems to vary from study to study, but consensus has been reached about the diversity of the possible cardiac lesions.

Presentation could be as early as the neonatal period with convulsions due to hypocalcaemia or cyanosis and/or heart failure depending on severity and location of cardiac lesion ${ }^{6}$. Subsequently recurrent infections (fungal/opportunistic/bacterial) contribute to morbidity ${ }^{6}$.
All patients suspected to have DGA or other related 22q11.2 deletion should have an immunological evaluation including lymphocyte subset analysis, Tlymphocyte proliferative responses, immunoglobulin levels and specific antibody responses ${ }^{7}$.

Since diagnosis of DGA is based on presence of congenital cardiac malformations, hypocalcaemia secondary to hypoparathyroidism and a small or absent thymus, we decided that our patient fits into a partial form of Di George syndrome, as a sporadic occurrence.

If facilities are available we would recommend a full assessment of immune system while concentrating on T-cell proliferative responses to mitogens and FISH probe to detect microdeletions of ch.22q11. In this patient, since facilities to assess immune functions were not available, we decided to continue a prophylactic regime of cotrimoxazole and calcium supplements along with vitamin D and regular follow-up for treatment of recurrent sinopulmonary infections as and when required.

\section{References}

1. Lammer E J, Opitz J M. The Di George anomaly as a developmental field defect. Am J Med Genet Suppl 1986; 2: 113-27.

2. Driscoll D A, Budarf M L, Emanuel B S. A genetic etiology for Di George syndrome: consistent deletions and microdeletions of 22q11. Am J Hum Genet 1992; 50: 924-33.

3. Hong R. The Di George anomaly (CATCH 22, DiGeorge/velocardiofacial syndrome). Semin Hematol 1998; 35(4): 282-90.

4. Muller W, Peter H H, Wilken M. Di George syndrome. Clinical evaluation and course of partial and complete forms of the syndrome. Eur J Pediatr 1988; 147(5): 496-502.

5. Ryan A K, Goodship J A, Wilson D A. Spectrum of clinical features associated with interstitial chromosome 22q11 deletions. $J$ Med Genet 1997; 34: 798-804.

6. Conley M E, Beckwith J B, Mancer J F, Tenckhoff L. Spectrum of the Di George syndrome. J Pediatr 1979; 94(6): 883-90.

7. Barrett D J, Ammann A J, Wara D W. Clinical and immunologic spectrum of $\mathrm{Di}$ George syndrome. J Clin Lab Immunol 1981; 6(1): 1-6. 
